\title{
Coronally advanced flap surgery with enamel matrix derivative in the treatment of gingival recession: a systematic review
}

Yan de Lima Barrozo ${ }^{a}$, Virgínia Régia Souza da Silveira ${ }^{b}$, Ricardo Souza Martins ${ }^{c}$, Rosimary de Sousa Carvalho ${ }^{d}$, Maria Mônica Studart Mendes Moreira ${ }^{d}$

\begin{abstract}
Objective: Based on a review of the literature, we evaluated the clinical effect of the combination of enamel matrix derivative proteins (EMDP) and coronally advanced flap (CAF) surgery in the treatment of gingival recession (GR).

Methods: Information was retrieved from the electronic databases PubMed, Lilacs, Scielo, Medline and the Cochrane Library. Controlled, randomized clinical studies of intervention in humans published in English or Spanish between 2000 and 2013 were eligible.

Results: The initial sample consisted of 171 publications. Of these, eight were selected which compared CAF+EMDP (study) with CAF alone (control) in the treatment of GR. Invariably, RH decreased in both the study group and the control group. Likewise, GR width and probing depth decreased and the clinical attachment level increased in both groups, but results were significantly better in the study group.

Conclusion: Despite the absence of an overall significant difference between treatment with CAF + EMDP and CAF alone, the addition of EMDP appears to increase the likelihood of achieving complete root coverage and clinically and aesthetically satisfactory results.
\end{abstract}

Key words: Gingival recession; Enamel matrix derivative; Coronally advanced flap

\section{Retalho posicionado coronariamente associado à proteína derivada da matriz do esmalte no tratamento de recessões gengivais: revisão sistematizada da literatura}

\section{RESUMO}

Objetivo: Este estudo avaliou por meio de uma revisão da literatura, o efeito clínico do retalho posicionado coronariamente (RPC) associado a proteínas derivadas da matriz do esmalte (PDME) no tratamento das recessões gengivais $(\mathrm{RG})$

Metodologia: Foram consultadas bases de dados eletrônicas: PubMed, Lilacs, Scielo, Medline e o Centro de Registro de Ensaios Clínicos Controlados e incluídos estudos clínicos de intervenção em humanos, randomizados, controlados, publicados em língua inglesa ou espanhola, entre 2000 e 2013.

Resultados: Foram encontradas 171 referências e com a análise dos títulos e resumos, oito estudos que abordaram aplicação de PDME em associação com o RPC para o tratamento de RG, que utilizavam no grupo controle apenas RPC, fizeram parte desta revisão. Esses trabalhos relataram uma redução significativa na altura das RG tratadas com RPC e RPC+PDME. Houve redução da largura da RG e profundidade de sondagem, com ganhos no nível de inserção clínica em ambos os tratamentos, com melhores resultados no grupo RPC + PDME. Conclusões: Apesar de não existirem diferenças significativas em um aspecto geral na cobertura radicular com o uso do RPC isolado ou combinado com PDME, esta combinação pode favorecer o recobrimento radicular completo ou melhorar os níveis de recobrimento radicular.

Palavras-chave: Recessão gengival; Proteína derivada da matriz do esmalte; Retalho posicionado coronaralmente a School of Pharmacy, Dentistry and Nursing, Federal University of Ceará, Fortaleza, CE, Brazil. ${ }^{b}$ Graduate Program in Dentistry, School of Pharmacy, Dentistry and Nursing, Federal University of Ceará, Fortaleza, CE, Brazil.

${ }^{c}$ Assistant Professor, Discipline of Periodontology, School of Pharmacy, Dentistry and Nursing, Federal University of Ceara, Fortaleza, CE, Brazil.

${ }^{d}$ Associate Professor, Discipline of Periodontology, School of Pharmacy, Dentistry and Nursing, Federal University of Ceara, Fortaleza, CE, Brazil.

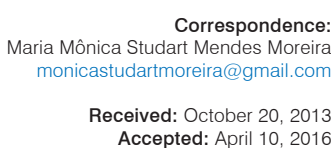

Accepted: April 10, 2016

Conflict of Interests: The authors state that there re no financial and personal conflicts of interest that could have inappropriately influenced their work.

Copyright: ๑ 2016 Barrozo et al. licensee EDIPUCRS.

This work is licensed under a Creative Commons Attribution 4.0 International License. 


\section{INTRODUCTION}

Gingival recession (GR) occurs when the gingival margin is apical to the cementoenamel junction, clinically resulting in exposure of the root surface and loss of attachment [1]. The etiology of GR involves a wide range of factors, including periodontal disease, excessive tooth-brushing force, iatrogenesis (orthodontic tooth movement, defective fillings) and anatomical conditions (mal-positioned teeth, muscle attachment, abnormal frenum attachment) [2]. GR affects populations regardless of their standards of oral hygiene [3]. Associated with pain and dental tenderness, the condition can compromise aesthetics and dental vitality [4]. It is also an important risk factor for the development of root caries $[4,5]$.

GR may be classified according to severity based on the prognosis of root coverage with mucogingival surgical procedures [6]. Thus, patients with Miller's class I and II GR present no periodontal attachment loss in the interproximal area and complete root coverage is achievable. In Miller's class III GR, loss of periodontal attachment is mild to moderate and only partial root coverage is achievable. Finally, in Miller's class IV GR, interproximal tissue loss is so severe that no root coverage is possible [6].

The choice of surgical technique for root coverage in GR depends mainly on patient demands and on local anatomical characteristics, such as recession height and width, interdental soft tissue dimensions, recessions in adjacent teeth, root caries and cervical abrasions [7].

A range of plastic surgery procedures have been proposed for the treatment of GR, including free gingival graft (FGG), connective tissue graft (CTG), guided tissue regeneration (GTR) and pedicled flaps (PF) [8].

One of the most widely used surgical techniques of root coverage is coronally advanced flap (CAF) [9]. When this technique is used in patients with Miller's class I and II GR, the average root coverage achieved is between $64 \%$ [10] and 99\% [11], and the aesthetic results are generally excellent, with no need for a second surgical site. The procedure is simple to perform and may be used to treat multiple recessions as well [12].

Several clinical studies have explored the combination of enamel matrix derivative proteins (EMDP) and surgical root coverage procedures (especially CAF) in order to improve root coverage predictability and periodontal regeneration of the previously exposed root surface [13-18]. Histological analyses of bone defects treated with EMDP show the formation of a new acellular extrinsic fiber cementum attached to the underlying dentin. In addition, a new periodontal ligament, including the attachment of functionally oriented collagen fibers and alveolar bone, may be observed [19].

The purpose of the present study was to compare the clinical effect of CAF with and without EMDP in the treatment of gingival recession, based on a review of the literature.

\section{METHODOLOGY}

The review of the literature was based on a search in electronic databases, including PubMed, Lilacs, Scielo, Medline and the Cochrane Library, using the following descriptors: coronally advanced flap, enamel matrix proteins, root coverage and gingival recession. The search was narrowed by selecting only controlled, randomized clinical studies of intervention in humans published in English or Spanish between 2000 and 2013. The initial sample consisted of 171 abstracts. After analyzing the titles and abstracts, the complete texts were retrieved and screened using the following criteria:

- blind or double-blind study,

- type of intervention: use of combination of EMDP and CAF in the treatment of single or multiple GR,

- control group: GR treated with CAF alone.

To minimize the risk of bias, the selected articles were analyzed by two independent reviewers (Y.L.B. and V.R.S.S.). Discrepancies regarding the eligibility of articles were discussed extensively by the reviewers. When an agreement could not be reached, a third investigator (M.M.S.M.M.) was consulted. The final sample consisted of 8 publications.

\section{RESULTS}

Table 1 shows in chronological order the main characteristics of clinical studies comparing the clinical effect of CAF with and without EMDP in the treatment of gingival recession [20-27].

The following eight publications were included in the final analysis: Modica et al. [20], Hägewald et al. [21), Cueva et al. [22], Del Pizzo et al. [23], Spahr et al. [24), Castellanos et al. [25], Pilloni et al. [26] and Cordaro et al. [27]. The study by Cueva et al. [22], included patients with Miller's class III GR, but the number of patients in this category was not specified.

The seven most important clinical parameters evaluated in these articles were: recession height (RH), recession width $(\mathrm{RW})$, probing depth (PD), clinical attachment level (CAL), keratinized tissue width (KT), alveolar bone level (ABL) and percentage root coverage (RC). However, not all the studies in the sample evaluated all seven parameters.

\section{Recession height $(\mathrm{RH})$}

This parameter was evaluated in all the studies. Invariably, RH decreased in both the study group (CAF + EMDP) and the control group (CAF) but the reduction was greater in the former [20-17]. However, the difference in RH between the study group and the control group was only statistically significant in three studies: Cueva et al. [22] - reduction from $2.77 \pm 0.62 \mathrm{~mm}$ to $0.19 \pm 0.15 \mathrm{~mm}$ versus from $2.68 \pm 0.65$ $\mathrm{mm}$ to $0.77 \pm 0.25 \mathrm{~mm}(p<0.001)$; Castellanos et al. [25] reduction from $2.68 \pm 1.63 \mathrm{~mm}$ to $0.36 \pm 0.60 \mathrm{~mm}$ versus from $2.31 \pm 1.52$ to $0.90 \pm 0.95 \mathrm{~mm}(p<0.05)$; and Pilloni et al. [26] - reduction from $2.86 \pm 0.64 \mathrm{~mm}$ to $0.13 \pm 0.06 \mathrm{~mm}$ versus from $2.66 \pm 0.70 \mathrm{~mm}$ to $1.53 \pm 0.50 \mathrm{~mm}(p<0.001)$. 
Table 1. Summary of the eight studies included in the present systematic review evaluating the clinical effect of coronally repositioned flap (CAF) surgery, alone or in combination with enamel matrix derivative proteins (EMDP), in the treatment of gingival recession.Continued Table 1.

\begin{tabular}{|c|c|c|c|c|c|c|c|}
\hline $\begin{array}{l}\text { Study } \\
\text { (year) }\end{array}$ & Methods & Participants & Intervention & $\begin{array}{l}\text { Evaluated clinical } \\
\text { parameters }\end{array}$ & $\begin{array}{c}\text { Type of recession } \\
\text { treated* }^{*}\end{array}$ & $\begin{array}{c}\text { Blinded } \\
\text { investigator }\end{array}$ & Main findings \\
\hline $\begin{array}{l}\text { Modica et al. } \\
(2000)[20]\end{array}$ & $\begin{array}{l}\text { Controlled } \\
\text { randomized clinical } \\
\text { trial, split-mouth } \\
\text { design, } 2 \text { groups, } \\
6 \text { months. }\end{array}$ & $\begin{array}{l}12 \text { subjects } \\
\text { ( } 7 \text { men / } 5 \text { women). } \\
\text { Average age: } \\
33.8 \text { years. } \\
\text { Non-smokers. }\end{array}$ & $\begin{array}{l}\text { Control group: CAF } \\
\text { (14 treated sites). } \\
\text { Study group: } \\
\text { CAF+EMDP } \\
\text { (14 treated sites). }\end{array}$ & $\mathrm{RH}, \mathrm{PD}, \mathrm{CAL}, \mathrm{KT}$. & $\begin{array}{l}\text { I and II } \\
\text { ( } 20 \text { isolated } \\
\text { defects with } \\
\mathrm{RH} \geq 3 \mathrm{~mm} \text {, and } \\
8 \text { multiple effects } \\
\text { with } \mathrm{RH} \geq 3 \mathrm{~mm} \text { ). }\end{array}$ & Yes. & $\begin{array}{l}\text { After } 6 \text { months, a } \\
\text { significant intragroup } \\
\text { difference was observed } \\
\text { with regard to CAL. } \\
\text { However, no significant } \\
\text { intergroup difference was } \\
\text { observed with regard to } \\
\text { any parameter (RH, PD, } \\
\text { CAL and KT). }\end{array}$ \\
\hline $\begin{array}{l}\text { Hägewald et al. } \\
\text { (2002) [21] }\end{array}$ & $\begin{array}{l}\text { Placebo-controlled } \\
\text { randomized clinical } \\
\text { trial, split-mouth } \\
\text { design, } 2 \text { groups, } \\
12 \text { months. }\end{array}$ & $\begin{array}{l}36 \text { subjects } \\
\text { (19 men / } 17 \text { women) } \\
\text { Average age: } \\
36 \text { years. } \\
\text { Non-smokers }\end{array}$ & $\begin{array}{l}\text { Control group: CAF+ } \\
\text { placebo (propylene } \\
\text { glycol alginate) } \\
\text { ( } 36 \text { treated sites). } \\
\text { Study group: } \\
\text { CAF+EMDP } \\
\text { (36 treated sites). }\end{array}$ & $\begin{array}{l}\mathrm{RH}, \mathrm{RW}, \mathrm{PD}, \mathrm{CAL} \text {, } \\
\mathrm{KT}, \mathrm{ABL} .\end{array}$ & $\begin{array}{l}\text { I and II } \\
\text { (72 isolated } \\
\text { defects with } \\
\mathrm{RH} \geq 3 \mathrm{~mm} \text { ). }\end{array}$ & Yes. & $\begin{array}{l}\text { After } 12 \text { months, both } \\
\text { groups had experienced } \\
\text { a similar increase in CAL. } \\
\text { Changes in KT were } \\
\text { significantly greater in the } \\
\text { study group ( } P=0.003 \text { ). } \\
\text { No significant difference } \\
\text { was observed for any } \\
\text { other parameter (RH, RW, } \\
\text { PD, CAL and ABL). }\end{array}$ \\
\hline $\begin{array}{l}\text { Cueva et al. } \\
(2004) \text { [22] }\end{array}$ & $\begin{array}{l}\text { Controlled } \\
\text { randomized clinical } \\
\text { trial, split-mouth } \\
\text { design, } 2 \text { groups, } \\
6 \text { months. }\end{array}$ & $\begin{array}{l}17 \text { subjects } \\
\text { (6 men / } 11 \text { women). } \\
\text { Average age: } \\
39 \text { years. } \\
2 \text { smokers }\end{array}$ & $\begin{array}{l}\text { Control group: CAF } \\
\text { (29 treated sites). } \\
\text { Study group: } \\
\text { CAF+EMDP } \\
\text { (29 treated sites). }\end{array}$ & $\begin{array}{l}\mathrm{RH}, \mathrm{RW}, \mathrm{PD}, \mathrm{CAL} \text {, } \\
\mathrm{RC}, \mathrm{KT} \text {. }\end{array}$ & $\begin{array}{l}\text { I, II and III } \\
\text { (20 isolated } \\
\text { defects with } \\
\mathrm{RH}>2 \mathrm{~mm} \text {, and } \\
38 \text { multiple effects } \\
\text { with } \mathrm{RH}>2 \mathrm{~mm} \text { ). }\end{array}$ & Yes. & $\begin{array}{l}\text { After } 6 \text { months, the } \\
\text { study group presented } \\
\text { significantly smaller } \\
\text { RH and RW values and } \\
\text { significantly greater } \\
\text { RC }(p<0.001) \text { and KT } \\
(p<0.005) \text { values. }\end{array}$ \\
\hline $\begin{array}{l}\text { Del Pizzo et al. } \\
\text { (2005) [23] }\end{array}$ & $\begin{array}{l}\text { Placebo-controlled } \\
\text { randomized clinical } \\
\text { trial, split-mouth } \\
\text { design, } 2 \text { groups, } \\
24 \text { months. }\end{array}$ & $\begin{array}{l}15 \text { subjects } \\
\text { ( } 4 \text { men/11 women). } \\
\text { Average age: } \\
39.46 \text { years. } \\
\text { Non-smokers. }\end{array}$ & $\begin{array}{l}\text { Control group: CAF+ } \\
\text { placebo (propylene } \\
\text { glycol alginate) } \\
\text { (15 treated sites). } \\
\text { Study group: } \\
\text { CAF+EMDP } \\
\text { (15 treated sites). }\end{array}$ & $\begin{array}{l}\mathrm{RH}, \mathrm{RW}, \mathrm{PD}, \mathrm{CAL} \text {, } \\
\mathrm{KT} \text {. }\end{array}$ & $\begin{array}{l}\text { I and II } \\
\text { (30 isolated } \\
\text { defects with RH } \\
\geq 3 \mathrm{~mm} \text { ). }\end{array}$ & Yes. & $\begin{array}{l}\text { After } 24 \text { months, no } \\
\text { significant intergroup } \\
\text { difference was found } \\
\text { for the parameters } \mathrm{RH} \text {, } \\
\mathrm{RW}, \mathrm{PD}, \mathrm{CAL} \text { and } \mathrm{KT} \text {, } \\
\text { but significant intragroup } \\
\text { differences were observed } \\
\text { for } \mathrm{RH} \text { and LAC. }\end{array}$ \\
\hline $\begin{array}{l}\text { Spahr et al. } \\
\text { (2005) [24] }\end{array}$ & $\begin{array}{l}\text { Controlled } \\
\text { randomized clinical } \\
\text { trial, split-mouth } \\
\text { design, } 2 \text { groups, } \\
24 \text { months. }\end{array}$ & $\begin{array}{l}30 \text { subjects } \\
\text { (18 men/12 women). } \\
\text { Average age: } \\
36.5 \text { years. } \\
5 \text { smokers ( }<10 \\
\text { cigarettes per day). }\end{array}$ & $\begin{array}{l}\text { Control group: CAF } \\
\text { ( } 30 \text { treated sites). } \\
\text { Study group: } \\
\text { CAF+EMDP } \\
\text { ( } 30 \text { treated sites). }\end{array}$ & $\begin{array}{l}\mathrm{RH}, \mathrm{RW}, \mathrm{PD}, \mathrm{CAL} \text {, } \\
\mathrm{KT}, \mathrm{ABL} .\end{array}$ & $\begin{array}{l}\text { I and II } \\
(60 \text { isolated } \\
\text { defects with } \\
\mathrm{RH} \geq 3 \mathrm{~mm} \text { ). }\end{array}$ & Yes. & $\begin{array}{l}\text { After } 24 \text { months, the } \\
\text { groups did not differ } \\
\text { significantly with regard } \\
\text { to } R H, K T, C A L \text { or } A B L \text {. } \\
\text { However, PD }(p=0.0463) \\
\text { and RW ( } p=0.0274) \\
\text { improved significantly in } \\
\text { the study group. }\end{array}$ \\
\hline $\begin{array}{l}\text { Castellanos et al. } \\
\text { (2006) [25] }\end{array}$ & $\begin{array}{l}\text { Controlled } \\
\text { randomized clinical } \\
\text { trial, parallel } \\
\text { design, } 2 \text { groups, } \\
12 \text { months. }\end{array}$ & $\begin{array}{l}22 \text { subjects } \\
\text { ( } 9 \text { men/13 women). } \\
\text { Average age: } \\
42.5 \text { years. } \\
\text { Non-smokers. }\end{array}$ & $\begin{array}{l}\text { Control group: CAF } \\
\text { (11 treated sites). } \\
\text { Study group: } \\
\text { CAF+EMDP } \\
\text { (11 treated sites). }\end{array}$ & $\begin{array}{l}\mathrm{RH}, \mathrm{RW}, \mathrm{PD}, \mathrm{CAL} \text {, } \\
\mathrm{KT} \text {. }\end{array}$ & $\begin{array}{l}\text { I and II } \\
\text { (22 isolated } \\
\text { defects with } \\
\mathrm{RH}>2 \mathrm{~mm} \text { ). }\end{array}$ & Not specified. & $\begin{array}{l}\text { After } 12 \text { months, } \mathrm{RH} \\
\text { and RW values were } \\
\text { significantly higher in } \\
\text { the study group. In both } \\
\text { groups, the increase in } \\
\mathrm{RC}, \mathrm{CAL} \text { and KT was } \\
\text { significant. The groups did } \\
\text { not differ significantly with } \\
\text { regard to PD and CAL. }\end{array}$ \\
\hline $\begin{array}{l}\text { Pilloni et al. } \\
\text { (2006) [26] }\end{array}$ & $\begin{array}{l}\text { Controlled } \\
\text { randomized clinical } \\
\text { trial, parallel } \\
\text { design, } 2 \text { groups, } \\
18 \text { months. }\end{array}$ & $\begin{array}{l}30 \text { subjects } \\
\text { (17 men/13 women). } \\
\text { Age range: } \\
\text { 19-67 years. } \\
\text { Non-smokers. }\end{array}$ & $\begin{array}{l}\text { Control group: CAF } \\
\text { (15 treated sites). } \\
\text { Study group: } \\
\text { CAF+EMDP } \\
\text { (15 treated sites). }\end{array}$ & $\mathrm{RH}, \mathrm{PD}, \mathrm{CAL}, \mathrm{KT}$. & $\begin{array}{l}\text { I and II } \\
\text { ( } 30 \text { isolated and } \\
\text { multiple defects, } \\
\text { minimum size } \\
\text { not specified). }\end{array}$ & Yes. & $\begin{array}{l}\text { After } 18 \text { months, the } \\
\text { groups did not differ } \\
\text { significantly with regard } \\
\text { to } P D \text {, but } R H(p<0.01) \text {, } \\
\text { CAL }(p<0.001) \text { and } \\
\text { KT }(p<0.05) \text { improved } \\
\text { significantly in the study } \\
\text { group compared to the } \\
\text { control group. }\end{array}$ \\
\hline $\begin{array}{l}\text { Cordaro et al. } \\
\text { (2012) [27] }\end{array}$ & $\begin{array}{l}\text { Controlled } \\
\text { randomized clinical } \\
\text { trial, split-mouth } \\
\text { design, } 2 \text { groups, } \\
24 \text { months. }\end{array}$ & $\begin{array}{l}10 \text { subjects } \\
\text { (gender ratio } \\
\text { not specified). } \\
\text { Age range: } \\
18-60 \text { years. } \\
\text { Number of smokers } \\
\text { not specified. }\end{array}$ & $\begin{array}{l}\text { Control group: CAF } \\
\text { ( } 29 \text { treated sites). } \\
\text { Study group: } \\
\text { CAF+EMDP } \\
\text { (29 treated sites). }\end{array}$ & $\mathrm{RH}, \mathrm{PD}, \mathrm{CAL}, \mathrm{KT}$. & $\begin{array}{l}\text { I and II } \\
\text { (58 multiple } \\
\text { defects with } \\
\mathrm{RH} \geq 2 \mathrm{~mm} \text { ). }\end{array}$ & Yes. & $\begin{array}{l}\text { After } 24 \text { months, no } \\
\text { siginificant differences } \\
\text { were observed between } \\
\text { the groups with regard to } \\
\text { any parameter ( } \mathrm{RH}, \mathrm{PD} \text {, } \\
\text { CAL and KT). }\end{array}$ \\
\hline
\end{tabular}

$\mathrm{RH}=$ recession height; $\mathrm{RW}=$ recession width; $\mathrm{PD}=$ probing depth; $\mathrm{CAL}=$ clinical attachment level; $\mathrm{KT}=$ keratinized tissue width; $\mathrm{ABL}=$ alveolar bone level; $\mathrm{RC}=$ percentage root coverage; CAF = coronally advanced flap; PDME = enamel matrix derivative proteins. 
Recession width (RW)

This parameter was not evaluated in three studies [20, $26,27]$. As for the other five studies, RW decreased in both the study group (CAF+EMDP) and the control group (CAF) but the reduction was invariably greater in the former. However, the difference in RH between the study group and the control group was only statistically significant in three studies $[22,24,25]$ : reduction from $3.92 \pm 0.36 \mathrm{~mm}$ to $0.80 \pm 0.50 \mathrm{~mm}$ versus from $3.80 \pm 0.30$ to $2.11 \pm 0.50 \mathrm{~mm}$ $(p<0.001)$ [22]; reduction from $4.33 \pm 0.77 \mathrm{~mm}$ to $2.88 \pm$ $1.61 \mathrm{~mm}$ versus from $4.42 \pm 0.81 \mathrm{~mm}$ to $1.95 \pm 1.72 \mathrm{~mm}$ $(p=0.0274)$ [24]; reduction from $4.27 \pm 2.06 \mathrm{~mm}$ to $0.77 \pm 0.87 \mathrm{~mm}$ versus from $3.68 \pm 1.91 \mathrm{~mm}$ to $1.72 \pm 1.31 \mathrm{~mm}$ $(p=0.025)[25]$.

\section{Probing depth (PD)}

This parameter was evaluated in all the studies. In seven studies [20-22,24-27), PD decreased in both the study group (CAF+EMDP) and the control group (CAF). The study by Del Pizzo et al. [23), was the only to report similar PD values regardless of treatment (group) and time (24 months). The difference in PD between the study group and the control group was statistically significant in only one study: reduction from $1.76 \pm 0.61 \mathrm{~mm}$ to $0.66 \pm 0.68 \mathrm{~mm}$ (study group) versus from $1.58 \pm 0.65 \mathrm{~mm}$ to $0.32 \pm 0.83 \mathrm{~mm}$ (control group) ( $p=0.0463)$ [24].

\section{Clinical attachment level (CAL)}

This parameter was evaluated in all the studies. Invariably, CAL decreased in both the study group (CAF+ EMDP) and the control group (CAF) but the reduction was greater in the former [20-27].

The difference in CAL between the study group and the control group was statistically significant in only one study [26]: reduction from $3.80 \pm 0.67 \mathrm{~mm}$ to $1.00 \pm 0.00 \mathrm{~mm}$ versus from $3.60 \pm 0.70 \mathrm{~mm}$ to $1.53 \pm 0.50 \mathrm{~mm}(p<0.001)$.

\section{Keratinized tissue width (KT)}

This parameter was evaluated in all the studies. In one study [26], KT decreased in the control group (CAF). In the other seven studies, KT increased in both the study group $(\mathrm{CAF}+\mathrm{EMDP})$ and the control group (CAF) but the increase was invariably greater in the former. However, the difference in KT between the study group and the control group was only statistically significant in three studies $[21,22,26]$ : increase from $2.10 \pm 1.00 \mathrm{~mm}$ to $2.80 \pm 0.90 \mathrm{~mm}$ versus from $2.40 \pm 1.00 \mathrm{~mm}$ to $2.70 \pm 0.9 \mathrm{~mm}(p=0.003)$ [21); increase from $2.04 \pm 0.55 \mathrm{~mm}$ to $2.64 \pm 0.28 \mathrm{~mm}$ versus from $2.14 \pm$ 0.43 para $2.09 \pm 0.24 \mathrm{~mm}(p=0.005)[22)$; increase from $1.80 \pm 0.75$ to $1.93 \pm 0.50 \mathrm{~mm}$ versus from $1.66 \pm 0.60 \mathrm{~mm}$ to $1.46 \pm 0.60 \mathrm{~mm}(p<0.05)[26)$.

\section{Alveolar bone level (ABL)}

This parameter was evaluated in only two studies [21, 24]. In both of these, ABL increased significantly after the treatment, but the groups did not differ significantly.
Percentage root coverage $(\mathrm{RC})$

The highest $\mathrm{RC}$ value $(93.8 \pm 12.9 \%)$ was that of the study group in Pilloni et al. [26], with complete coverage in 13 of 15 treated sites. The lowest RC value (62.2\%) was that of the control group in Castellanos et al. [25], with complete coverage in only 4 of 11 treated sites. In another study [22], 7 sites were initially identified as Miller's class III GR; of these, three were treated with EMDP, while four were controls. Complete coverage was achieved for two recessions in the former group and for one recession in the latter group.

\section{Histological findings}

Only one study provided histological information [25): gingival tissue on the buccal side treated with EMDP was evaluated microscopically following the removal of a tooth for orthodontic purposes. The margin of the junctional epithelium was coronal to the treated recession, as indicated by the level of root instrumentation, and regenerating supportive periodontal tissues were observed coronally to this area.

\section{DISCUSSION}

A range of techniques have been developed to achieve complete root coverage in patients with GR. In addition, modifications made over the years have improved the predictability of these procedures. In the past, FGG was widely used, with different levels of success $[28,29]$. Today, CTG, originally introduced by Langer and Langer [30) and CAF $[31,32]$, or a combination of these two techniques [33$35]$, are among the most popular procedures, with greatly improved predictability.

CTG is associated with high success rates and excellent aesthetic results in the short and long run when used in patients with Miller's class I and II GR. It is also used as a standard to evaluate other techniques of root coverage [36]. In fact, the percentage root coverage has been shown to be similar for recessions treated with CAF+EMDP and with $\mathrm{CAF}+\mathrm{CTG}$. According to the authors, the only advantage of adding CTG to the treatment was an increase in $\mathrm{KT}[18,37]$. In all the studies reviewed for this paper, KT values were higher in groups treated with CAF + EMDP than in groups treated with $\mathrm{CAF}$ alone, and in three studies the difference was significant $[21,22,26]$.

Thus, it may be concluded that, on the average, similar root coverage may be achieved with either combination (CAF+EMDP vs. CAF+CTG). However, since no second surgical site is needed with the combination CAF+EMDP, the procedure is associated with less postoperative discomfort [18]. In a study on dogs with induced GR treated surgically with either CAF or CAF + EMDP, histometrical analyses showed the two options to be similar with regard to root coverage and tissue repair [38].

Despite variations in results, microscopic analyses revealed newly formed cementum, with attachment of 
connective tissue fibers and islands of bone tissue in roots treated with EMDP $[39,40]$. These findings match the results of the only study included in the present review which reported periodontal regeneration in tissue analyzed histologically [25].

The role of EMDP in periodontal regeneration was demonstrated in experimental recessions by Heijl [41]. In that study, the new cementum was observed histologically to cover $73 \%$ of the initial defect, while ABL increased by $65 \%$.

The mechanism of EMDP-induced periodontal regeneration appears to involve periodontal ligament cells [42]. EMDP, of which amelogenins constitute a major component [43], seem to mimic the embrionary phases of odontogenesis mainly by promoting the formation of a cementum-like mineralized tissue which may serve as a matrix for repopulation with periodontal ligament cells $[44,45]$.

In patients with high aesthetic expectations, CAF is the procedure of choice, provided enough keratinized tissue is present apically to the exposed root $[7,46]$. The soft tissue used to cover the recession is similar to the original tissue with regard to color, texture and thickness, leading to satisfactory aesthetic results [47].

In a case series evaluated by Abbas et al. [17], the combination CAF+EMDP was found to be a predictable procedure in the correction of GR defects, with excellent results in terms of root coverage and clinical attachment. In the eight studies reviewed here, $100 \%$ root coverage was achieved for a total of 81 sites treated with CAF+EMDP, as opposed to 47 sites treated with CAF only. In addition, in all treated recessions CAL increased and $\mathrm{RH}$ and $\mathrm{RW}$ decreased, especially in the study group (CAF+EMDP). A systematic review and metanalysis [48] of the use of EMDP in periodontal therapy found that the combination CAF+EMDP was significantly more efficient than CAF alone with regard to root coverage (odds ratio: 3.5 ).

The authors of this review subscribe to the view that CAF is a safe and reliable periodontal plastic surgery procedure capable of reducing gingival recession and, in many cases, achieve complete root coverage. In the reviewed articles, the addition of EMDP produced similar results in terms of root coverage. Small, non-significant clinical differences in favor of the combination CAF+EMDP were found. In other systematic reviews $[48,49]$, the addition of EMDP improved root coverage outcomes.

The present review was limited by the short follow-up time of each study, by the lack of sample calculation and by the method of evaluation of clinical parameters.

\section{CONCLUSION}

The application of enamel matrix derivative proteins can improve the clinical outcome of surgical correction of gingival recession with coronally advanced flap technique, especially with regard to root coverage, keratinized tissue width and recession size. Thus, despite the absence of an overall significant difference between treatment with
CAF+ EMDP and with CAF alone, the addition of EMDP increases the likelihood of achieving complete root coverage and clinically and aesthetically satisfactory results.

\section{REFERENCES}

1. American Academy of Periodontology. Glossary of Periodontal Terms. 4a ed. Chicago: American Academy of Periodontology; 2001. p. 1-53.

2. Joshipura K, Kent R, De Paola P. Gingival recession: Intraoral distribution and associated factors. J Periodontol. 1994;65:864-71.

3. Löe $H$, Anerud A, Boysen $H$. The natural history of periodontal disease in man: Prevalence, severity and extent of gingival recession. J Periodontol. 1992;63:489-95

4. Albandar JM, Kingman A. Gingival Recession, Gingival Bleeding, and Dental Calculus in Adults 30 Years of Age and Older in the United States, 1988-1994. J Periodontol.1999;70:30-43.

5. DePaola PF, Soparkar PM, Tavares M, Kent R. The clinical profiles of individuals with and without root surface caries. Gerodontol. 1989;8:9-15

6. Miller PD. A classification of marginal tissue recession. Int J Periodontics Restorative Dent.1985;5:8-13

7. de Sanctis M, Zucchelli G. Coronally advanced flap: a modified surgical approach for isolated recession type defects: three-year results. J Clin Periodontol. 2007;34:262-68.

8. Jankovic S, Aleksic Z, Milinkovic I, Dimitrijevic B. The coronally advanced flap in combination with Platelet-rich Fibrin (PRF) and enamel matrix derivative in the treatment of gingival recession: A comparative study. Eur J Esthet Dent. 2010;5:260-73

9. Pini-Prato GP, Baldi C, Pagliaro U, Nieri M, Saletta D, Rotundo R, Cortellini P. Coronally advanced flap procedure for root coverage. Treatment of root surface: Root planning versus polishing. J Periodontol. 1999;70:1064-76.

10. Guinard, E. A. and Caffesse, R. G.: Treatment of localized gingival recessions, Part III. Comparison of results obtained with lateral sliding and coronally repositioned flaps. J Periodontol. 1978;49:457-61.

11. Harris RJ, Harris AW. The coronally positioned pedicle graft with inlaid margins: a predictable Method of Obtaining root coverage of shallow defects. Int J Periodontics Restorative Dent. 1994;25:229-41.

12. Berlucchi I, Francetti L, Del Fabbro M, Basso M, Weinstein RL. The influence of anatomical features on the outcome of gingival recessions treated with coronally advanced flap and enamel matrix derivative: a 1-year prospective study. J Periodontol. 2005;76:899-907.

13. Henriques PSG, Pelegrine AA, Nogueira AA, Borghi MM. Application of subepithelial connective tissue graft with or without enamel matrix derivative for root coverage: a split-mouth randomized study. J Oral Sci. 2010;52:463-71

14. Moriyama T, Matsumoto $S$, Makiishi T. Root coverage technique with enamel matrix derivative. Bull Tokio Dent Coll. 2009;50:97-104.

15. Kuru B, Yilmaz S, Noyan U. Treatment of gingival recession using enamel matrix proteins: a case report with 4-year follow-up. Quintessence Int. 2007;38:254-62

16. Moses O, Artzi Z, Sculean A, Tal H, Kozlovsky A, Romanos GE, Nemcovsky CE. Comparative study of two root coverage procedures: a 24-month follow-up multicenter study. J Periodontol. 2006;77:195-202.

17. Abbas F, Wennström J, Van der Weijden F, Schneiders T, Van der Velden $U$. Surgical treatment of gingival recessions using emdogain gel clinical procedure and case reports. Int J Periodontics Restorative Dent 2003;23:607-13

18. McGuire MK, Numm M. Evaluation of human recession defects treated with coronally advanced flaps and either enamel matrix derivative or connective tissue. Part 1: comparison of clinical parameters. J Periodontol. 2003; 74:1110-25

19. Heijl L. Periodontal regeneration with enamel matrix derivative in one human experimental defect: a case report. J Clin Periodontol. 1997;24:693-96.

20. Modica F, Del Pizzo M, Roccuzzo M, Romagnoli R. Coronally advanced flap for the treatment of buccal gingival recessions with and without enamel matrix derivative: a split-mouth study. J Periodontol. 2000;71:1693-8.

21. Hägewald S, Spahr A, Rompola E, Holler B, Heijl L, Bernimoulm J-P. Comparative study of Emdogain ${ }^{\circledR}$ and coronally advanced flap technique in the treatment of human gingival recessions: a prospective controlled clinical study. J Clin Periodontol. 2002;29:35-41.

22. Cueva MA, Boltchi FA, Hallmon WW, Nunn ME, Rivera-Hidalgo F, Rees T. A comparative study of coronally advanced flaps with and without the addition of enamel matrix derivative in the treatment of marginal tissue recession. J Periodontol. 2004;75:949-56. 
23. Del Pizzo M, Zucchelli G, Modica F, Villa R, Debernardi C. Coronally advanced flap with or without enamel matrix derivative for root coverage: a 2-year study. J Clin Periodontol. 2005:32:1181-7.

24. Spahr A, Hägewald S, Tsoulfidou F, Rompola E, Heijl L. Coverage of Miller class I and II recession defects using enamel matrix proteins versus coronally advanced flap technique: a 2-year report. J Periodontol. 2005; $76: 1871-80$.

25. Castellanos AT, de la Rosa MR, de la Garza M, Caffesse RG. Ename matrix derivative and coronal flaps to cover marginal tissue recessions. J Periodontol. 2006;77:7-14

26. Pilloni A, Paolantonio M, Camargo PM. Root coverage with coronally positioned flap used in combination with enamel matrix derivative: 18-month clinical evaluation. J Periodontol. 2006;77:2031-9.

27. Cordaro L, di Torresanto VM, Torsello F. Split-Mouth comparison of a coronally advanced flap with or without enamel matrix derivative for coverage of multiple gingival recession defects: 6- and 24-month followup. Int J Periodontics Restorative Dent. 2012;32:10-20.

28. Miller PD. Root coverage using a free soft tissue autograft following citric acid application. Part 1: Technique. Int J Periodontics Restorative Dent. 1982;2:65-70

29. Holbrook T, Ochsenbein C. Complete coverage of the denuded root surface with a one-stage gingival graft. Int $\mathrm{J}$ Periodontics Restorative Dent.1983;3:8-27.

30. Langer B, Langer L. Subepithelial connective tissue graft technique for root coverage. J Periodontol.1985;56:715-20.

31. Allen EP, Miller PD. Coronal positioning of existing gingiva: short term results in the treatment of shallow marginal tissue recession. J Periodontol. 1989:60:316-9.

32. Tarnow DP. Semilunar coronally repositioned flap. J Clin Periodontol 1986;13:182-85

33. Nelson SW. The subpedicle connective tissue graft. A bilamina reconstructive procedure for the coverage of denuded root surfaces. J Periodontol. 1987:58:95-102.

34. Maynard J. Coronal positioning of a previously placed autogenous gingival graft. J Periodontol. 1977;48:151-5.

35. Bernimoulin JP, Lüscher B, Mühlemann HR. Coronally repositioned periodontal flap. Clinical evaluation after one year. J Clin Periodontol. 1975;2:1-13.

36. Greenwell H, Bissada NF, Henderson RD, Dodge JR. The deceptive nature of root coverage results. J Periodontol. 2000;71:1327-37.

37. Berlucchi I, Francetti L, Del Fabbro M, Testori T, Weinstein RL. Ename matrix proteins (Emdogain) in combination with coronally advanced flap or subepithelial connective tissue graft in the treatment of shallow gingival recessions. Int J Periodontics Restorative Dent. 2002;22:583-93.

38. Sallum EA, Casati MZ, Caffesse RG, Funis LP, NocitiJúnior FH, Sallum AW Coronally positioned flap with or without enamel matrix protein derivated for the treatment of gingival recessions. Am J Dent. 2003;16:287-91.

39. Rasperini G, Silvestri M, Schenk RK, Nevins ML. Clinical and histologic evaluation of human gingival recession treated with a subepithelial connective tissue graft and enamel matrix derivative (Emdogain): A case report. Int J Periodontics Restorative Dent. 2000;20:269-75.

40. McGuire MK, Cochran DL. Evaluation of human recession defects treated with coronally advanced flaps and either enamel matrix derivative or connective tissue. Part 2: Histological evaluation. J Periodontol. 2003; $74: 1126-35$

41. Heijl L. Periodontal regeneration with enamel matrix derivative in one human experimental defect. A case report. J Clin Periodontol. 1997;24:693-6.

42. Hammarström L. Enamel matrix, cementum development and regeneration. J Clin Periodontol. 1997;24:658-68.

43. Brookes SJ, Robinson C, Kirkham J, Bonass WA. Biochemistry and molecular biology of amelogenin proteins of developing dental enamel. Archs Oral Biol. 1995;40:1-14

44. Hammarström L, Heijl L, Gestrelius S. Periodontal regeneration in a buccal dehiscence model in monkeys after application of enamel matrix proteins. J Clin Periodontol. 1997:24:669-77.

45. Gestrelius S, Lyngstadaas SP, Hammarström L. Emdogain: Periodontal regeneration based on biominicry. Clin Oral Investig. 2000;4:120-5.

46. Zucchelli G, De Sanctis M. Treatment of multiple recession-type defects in patients with esthetic demands. J Periodontol. 2000;71:1506-14

47. Zucchelli G, Mele M, Mazzotti C, Marzadori M, Montebugnoli L, De Sanctis M. Coronally advanced flap with and without vertical releasing incisions for the treatment of multiple gingival recessions: a comparative controlled randomized clinical trial. J Periodontol. 2009:80:1083-94.

48. Koop R, Merheb J, Quirynen M. Periodontal Regeneration With Enamel Matrix Derivative in Reconstructive Periodontal Therapy: A Systematic Review. J Periodontol. 2012;83:707-20.

49. Cairo F, Pagliaro U, Nieri M. Treatment of gingival recession with coronally advanced flap procedures: a systematic review. J Clin Periodontol. 2008;35:136-62. 